\title{
Building and District Data Organization to Improve Facility and Property Management
}

\author{
Mario Claudio Dejaco, Fulvio Re Cecconi, Nicola Moretti, \\ Antonino Mannino and Sebastiano Maltese
}

\begin{abstract}
Effective Facility Management services are a key issue for a high-quality built environment, both in the public and private sectors. Within this context, an information management framework for the use phase of assets has been developed with the aim to streamline real estate management processes. The framework allows users to access and update at any time technical, administrative and maintenance data both at the building and at the district level. This allows for the integrated management of physical assets and enhances the risk prevention strategy.
\end{abstract}

Keywords Facility management (FM) • Urban facility management (UFM) • Building/district information model (BIM/DIM)

\section{Introduction}

Production, collection and management of information relating to the built environment involve different players, belonging to the public or private sector (Volk et al. 2014). The public player assumes a role that is twofold: on one hand it has a legislative role making decisions also on the types of information which must be collected, stored and provided (when requested) to validate interventions on buildings. On the other hand, it is itself one of the players which must produce, collect and preserve that kind of mandatory information.

Moreover, it plays the role of controller; since it is responsible for monitoring the reliability and accuracy of the documentation which the private player must deliver, during the execution of the building process (design, execution, use and management

M. C. Dejaco $(\varangle) \cdot$ F. Re Cecconi · N. Moretti · A. Mannino

Architecture, Built Environment and Construction Engineering-ABC Department, Politecnico di Milano, Milan, Italy

e-mail: mario.dejaco@polimi.it

S. Maltese

Institute for Applied Sustainability to the Built Environment, University of Applied Sciences and Arts of Southern Switzerland-SUPSI, Canobbio, Switzerland 
of buildings), both in the case of a public or a private investments. According to this, it can be stated that public administration plays both a proactive and coercive role.

The private player is obliged to produce at least the documentation required by law, relating to its real estate properties. Moreover, it is responsible for updating and managing this information. The private player collects and produces data, since it is obliged by the public player. Nevertheless, in the case of a transaction or modification of existing assets, the owner can refer to that documentation, in order to set a better business process and ease the due diligence process.

In this context, tools for data collection and management assume a key role at the building and district level, especially in the context of facility and property management, in those places and areas where the competence and responsibility between the players is not clear (Lee et al. 2018; Mignard and Nicolle 2014). Therefore, the Building and the District Logbook could be considered risk prevention tools, both for public and private operators.

\section{Information Management for Built Environments}

One of the most critical issues to consider in built environment management concerns the collection, management and use of information, as different skills, needs and operators coexist, and where competencies among players are not always clear. Another problem concerns management areas where, for instance, connections of systems from the public to the private network are not well defined, when private areas used as public spaces and occupation of public property are not clear. In this situation rules and competencies are not always defined properly, with regards to both private and public responsibilities.

Usually, not considering peculiar cases that need to be analysed carefully, the city environment can be divided into open space and buildings (Gabellini 2012). Tangible, but also intangible goods that can be found in this context must be managed, in order to achieve a higher level of quality of spaces and life. Typically, the discipline the management of these matters is Facility Management (FM). Recently, FM has been declined at the urban level as Urban Facility Management (UFM), in order to achieve a more comprehensive strategy for quality improvement of the built and open environment (Sharifi and Murayama 2014). Within this context, the UNI 11447: 2012 (2012) provides a breakdown structure, useful for the determination of UFM services.

According to this classification, services can be applied to buildings, neighbourhoods and the city as a whole: the scale of complexity, in terms of stakeholders, elements, systems, entities to be managed, methods and procedures increase remarkably (Lotfi et al. 2008).

At the building and urban level, the ownership and stakeholder structure, in most cases, can be defined precisely, though there are certain situations where this subdivision cannot be performed easily; these contexts might cause disputes between owners and/or public administration and private bodies. 
The tools proposed in this paper, the Building and District "Logbooks", aim to streamline data management relating to building and urban spaces in order to facilitate the interaction among stakeholders and different players involved in management of the built environment. The proposed tools are not only intended to manage technical issues, but also to support a legal and economic dialogue.

The Building and the District Logbooks are both based on a sound structure for information management and they can be implemented in different moments of the assets' life cycle. Information can be exploited for different purposes: knowledge of building/urban areas; collection and management of technical/legislative issues; safety; conservation of economic value; law/regulation compliance of the building and the urban district (Dejaco et al. 2017a).

According to the phases of the physical assets' life cycle considered, the level of information can vary, though a minimum amount of data must always be present. Furthermore, the District Logbook can be considered a higher level of information repository to be employed for specific issues and characteristics relating to the single building, and vice versa (Dejaco et al. 2017b).

\section{Building Logbook}

The Building Logbook can be considered the repository of the documentation relating to a building. Its structure varies according to the characteristics of the building under analysis, according to the function, complexity and typology. In Table 1 its basic contents are identified.

Table 1 Contents of a Building Logbook (Dejaco et al. 2017b)

\begin{tabular}{l|l}
\hline Section & Information to be collected \\
\hline Building registry info & $\begin{array}{l}\text { Concerning the urban registry information and } \\
\text { the updated internal subdivision into sub-units }\end{array}$ \\
\hline Technical information on building elements & $\begin{array}{l}- \text { building breakdown } \\
- \text { description of technical, typological, } \\
\text { functional characteristic of components } \\
\text { (actual conditions) }\end{array}$ \\
\hline $\begin{array}{l}\text { Information on the property, management and } \\
\text { tenancy }\end{array}$ & $\begin{array}{l}- \text { updated documentation on ownership } \\
\text { updated documentation on tenancy and } \\
\text { related contracts and agreements } \\
- \text { documentation concerning the management } \\
\text { of the building (concerning leasing } \\
\text { contracts and technical management } \\
\text { contractors) }\end{array}$ \\
\hline $\begin{array}{l}\text { Operative information for management and } \\
\text { maintenance }\end{array}$ & $\begin{array}{l}\text { documentation relating to the technical, } \\
\text { administrative, economic management of } \\
\text { the building }\end{array}$ \\
& safety and certification \\
\hline
\end{tabular}



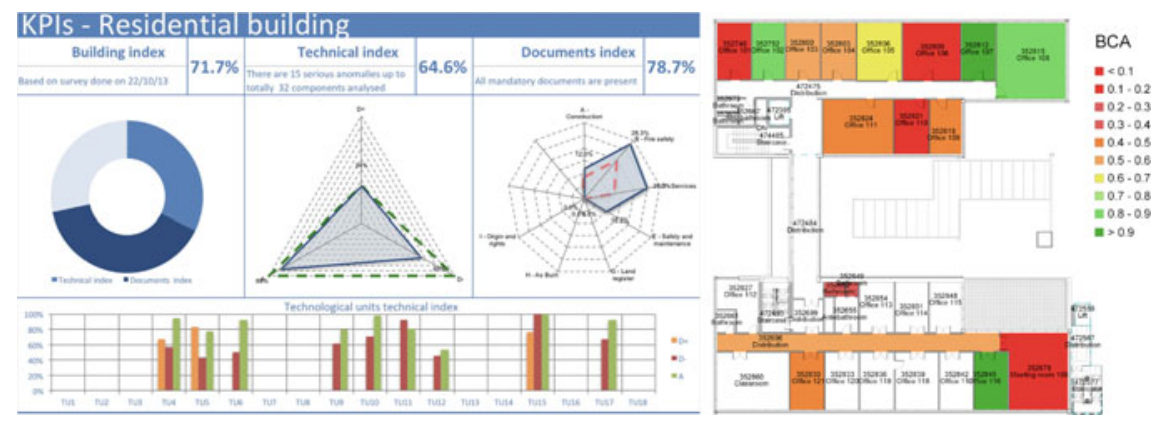

Fig. 1 Final synthetic report of a building assessment (Dejaco et al. 2017c; Re Cecconi et al. 2017)

This data is useful for all the stakeholders and for defining the conditions of a building during its life cycle from a technical, legislative and economic point of view. In the case of a new building, all the data come from the design and execution documentation; for an existing building it would be necessary to develop a specific building assessment and a documentation check. The result of this is represented in Fig. 1. Starting from a visual assessment of the building, it is possible to define a "technical index", representative of the state of its technical components; at the same time, the verification of the available documentation produces a similar "document index"; finally, a synthetic "building index" is computed. All of this data can be depicted in a graphic representation, highlighting technical elements, and/or those that referred to specific areas of the building. Detailed data (technical, documental, economic, ...) is collected into a databases, available for following analysis on behalf of different stakeholders.

Data entered through the use of digitized forms that can be filled out in the office during the design phase, or on site with a mobile device, during the construction and the use phases of the building (Figs. 2 and 3).

The data of this type, summarized and detailed, are useful in order to:

- define/check building maintenance and budget allocation;

- prioritize maintenance/refurbishment works and investments;

- compare conditions of the building with market value;

- program medium/long-term real estate management;

- support technical, economic and legal disputes between private or public operators.

\section{District Logbook}

The district logbook is a similar tool developed for information management at the urban level. The contents and the structure of this tool have been defined through an analysis of needs of the heterogeneous stakeholders involved in the management of 


\begin{tabular}{|c|c|c|c|c|c|}
\hline \multicolumn{2}{|l|}{ FORM DATA } & \multicolumn{4}{|c|}{ COMPONENT DATA } \\
\hline \multirow{2}{*}{\multicolumn{2}{|c|}{ FORM NUMBER }} & & CODE & \multicolumn{2}{|l|}{ NAME } \\
\hline & & COMPONENT & & & \\
\hline CODE & & TECHNOLOGICAL ELEMENTS CLASS & C.V. 01 & Opaque envelope & \\
\hline & C.V.01.01.03.01-s & TECHNOLOGICAL ELEMENT & C.V.01.01 & Vertical opaque envelope & \\
\hline \multirow{3}{*}{\multicolumn{2}{|c|}{ NAME }} & TYPOLOGY & C.V. 01.01 .03 & External finishing & \\
\hline & & MATERIAL & C.V.01.01.03.01 & Plaster on masonry & \\
\hline & & ASLL (Actual Service Life) & & & \\
\hline \multirow{2}{*}{\multicolumn{2}{|c|}{ SERVICE LIFE INDEX }} & \multicolumn{3}{|c|}{ ASLSRSL $\quad D^{+}=$} & \\
\hline & & \multicolumn{3}{|c|}{ ASLPSL $\quad D^{\prime}=$} & \\
\hline \multicolumn{2}{|l|}{ DEGRADATION INDEX } & \multicolumn{2}{|r|}{$A_{c}=$} & \multicolumn{2}{|l|}{1.000} \\
\hline \multicolumn{6}{|c|}{ ANOMALIES } \\
\hline TYPOLOGY & NAME & DESCRIPTION & PRESENCE $[\mathrm{Y} / \mathrm{N}]$ & INTENSITY & EXTENSION \\
\hline \multirow{3}{*}{$\begin{array}{l}\text { LOW } \\
\text { anomalies that compromise plaster } \\
\text { visual performances }\end{array}$} & Colour changing & $\begin{array}{l}\text { Variation of one or more } \\
\text { parameters that define the color } \\
\text { (hue, clarity, saturation), } \\
\text { discoloration of the finish, } \\
\text { oxidation and tarnishing of } \\
\text { surfaces, rust spots and permanent } \\
\text { stains on plaster and cement }\end{array}$ & & $\begin{array}{l}\text { Visibility of the degradation, contrast } \\
\text { level and residual brightness of } \\
\text { finishing }\end{array}$ & \\
\hline & Surface deposits & $\begin{array}{l}\text { Accumulation of urban } \\
\text { atmospheric dust or other foreign } \\
\text { material, of variable thickness, } \\
\text { inconsistent and not adhering to } \\
\text { the surface of the coating }\end{array}$ & & $\begin{array}{l}\text { Nature, texture and thickness of the } \\
\text { deposits }\end{array}$ & \\
\hline & $\ldots$ & -- & & -- & \\
\hline
\end{tabular}

Fig. 2 Example of an assessment schedule for a technical element (Re Cecconi et al. 2014)

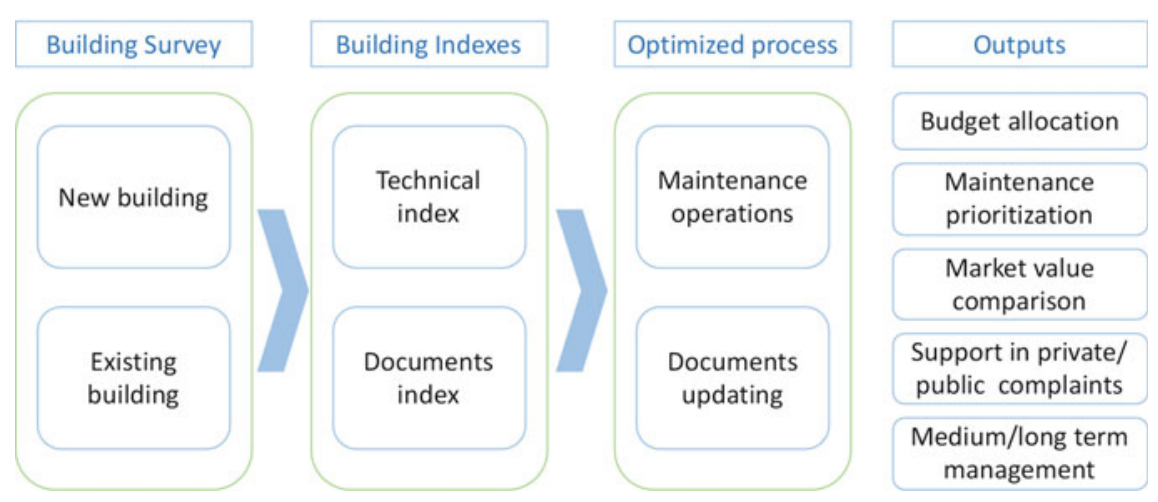

Fig. 3 Building Information Logbook process scheme

the city environment context. The main structure of the logbook has been defined as described in Table 2.

The contents can vary according to the life cycle phase in which the logbook is developed and to the specific case. In the management phase the completeness of the information is a remarkable issue, however, in this case, information can be collected gradually, starting from compulsory documentation concerning the city environment and its components. Also, for this tool the digitized forms can be filled out during different phases and by different operators, using a computer or through an on-site evaluation with a mobile device, developed by technical operators or involving the 
Tab. 2 Contents of a District Logbook (Dejaco et al. 2017b)

\begin{tabular}{l|l}
\hline Section & Information to be collected \\
\hline Urban and Building registry information & - general information about district \\
& - quantitative data and references to \\
& infrastructures, urban facilities and \\
& buildings \\
& - urban planning information and forecasts \\
\hline Technical information on urban goods and & - location \\
elements & - ownership, responsibility, manager \\
& - geometric info \\
\hline Population registry information, property & - data on the population of the district \\
management and tenancy & - data on city users \\
& - data on management entities \\
\hline Operative information for management and & - technical condition \\
maintenance & - instructions/procedures/guidelines for \\
& maintenance and management \\
& - safety and certification \\
\hline
\end{tabular}

community. In this case, adequate procedures for collection and filtering of data should be defined Fig. 4 .

It is important to underline that this information can be intended in different ways. On the one hand, it can be considered the data useful for a municipality to control and monitor the city districts, along with the services provided, to optimize the planning process. The data integrated in a proper database is useful in the setup phase of public tenders, and in the following implementation phase. In this sense, the District Logbook can be conceived as an information framework for monitoring tenders and public works.

\section{Assessment}

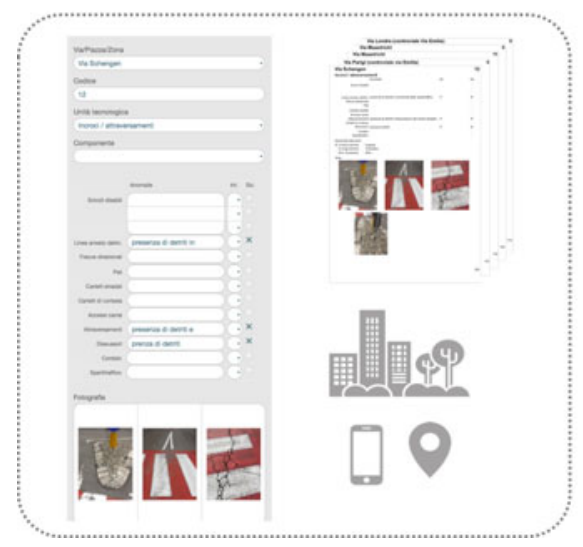

\section{Data analysis}

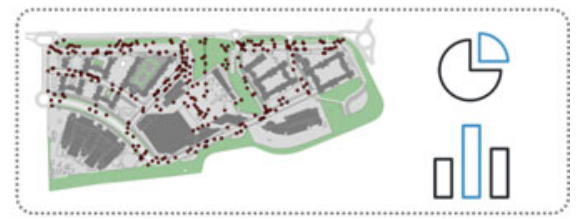

\section{Data output}

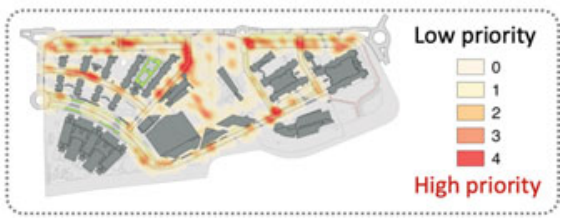

Fig. 4 Survey process, with the different phases of assessment, data analysis and data output (Moretti et al. 2018) 
On the other hand, the contents of the Logbook can be seen in terms of compliance with urban laws and codes, urban parameters and taxation issues, licenses and permissions, (a connection between the public and private domains). Therefore, in this case it can be seen as a tool supporting the coercive function of the public administration, in granting the safety and validity of the process, use of spaces and property.

\section{Facility and Property Process Support}

In a continuous improvement process, the information collected and managed with the Building and District Logbook application should be exploited to enhance the effectiveness of processes in the Public Private Partnership (PPP), leading to a shared approach to urban transformation and management. Data collected and updated during the life cycle (use and operational phases) of the building and/or of the district, can be employed for the condition assessment of the elements of the physical asset (building or urban area). Moreover, this data is a valuable support for making informed decisions Fig. 5.

The Building and District Logbook can be considered as two complementary tools, all the information managed can be intended as a support for the bidirectional sharing of data between public and/or private stakeholders, from the urban to the building level and vice versa.

The tools are able to handle data in different formats, including:

- graphical documentation (design, execution, use and operational phases);

- quantitative historical data concerning consistencies and costs;

- documentation concerning the use of the building (contracts, certifications, ...);

- ultimately the kind of data related to the specific use and typology of the property under investigation.

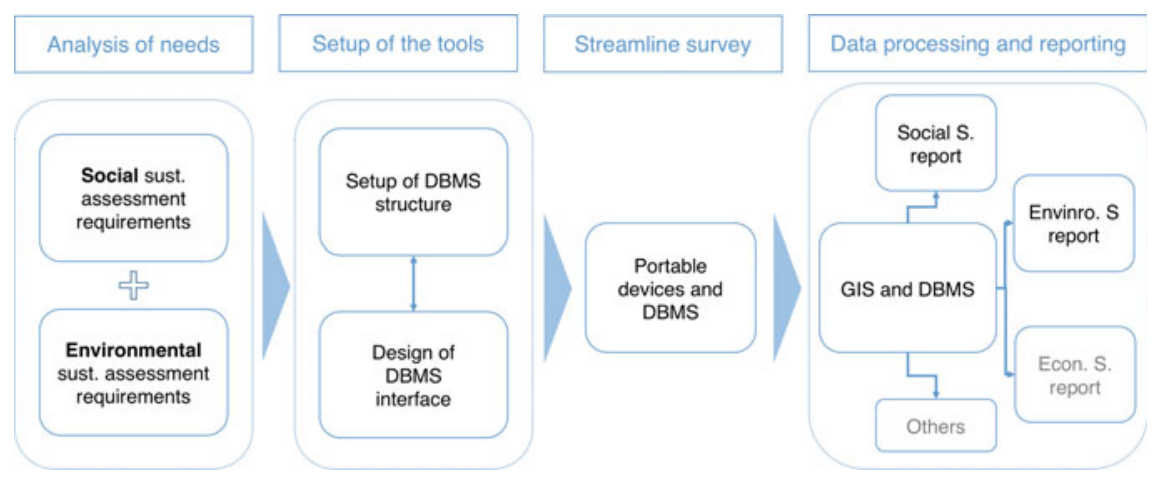

Fig. 5 District Information Model (DIM) as a consequence of the use of district logbooks (Moretti et al. 2017) 

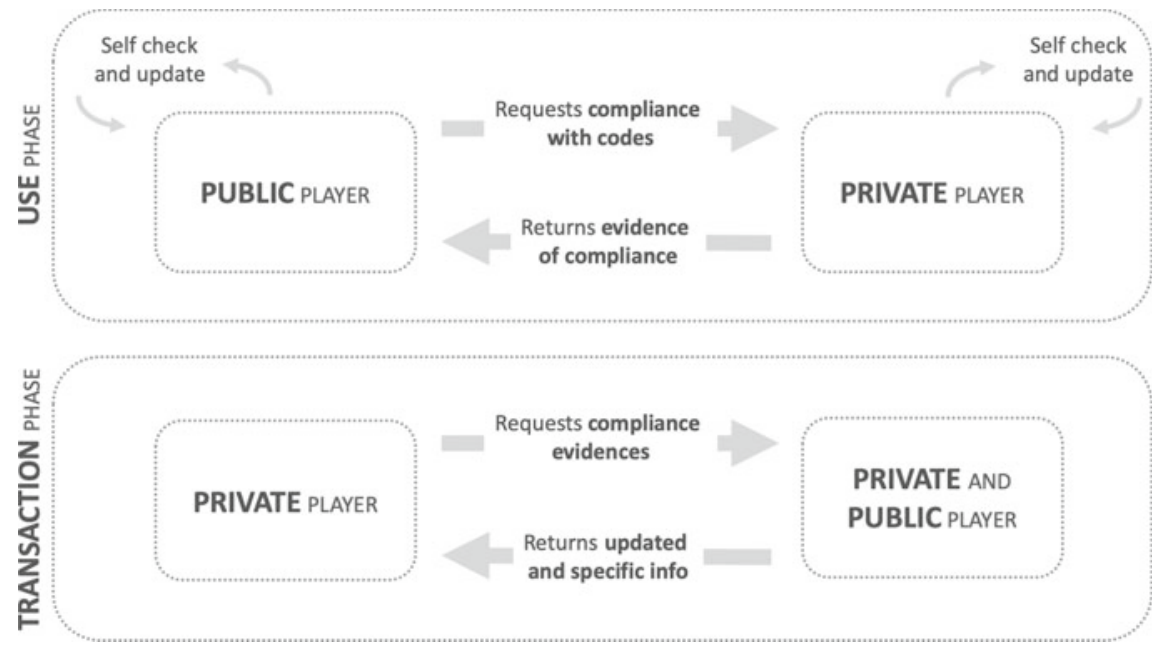

Fig. 6 A model/hypothesis of data flows in use and transaction phase (Dejaco et al. 2017b)

This data is a key for a variety of stages of the lifecycle of an asset, e.g., during the transaction and management phases (Fig. 6). Specifically, these tools should be used by the private players in terms of code and compliance checking and to have access to updated compulsory documentation concerning the asset. The public administration, on the other hand, assumes a double role of legislator and controlled entity, since it is simultaneously the issuer and the controller of codes and standards. Moreover, the public and the private players are in a mutual relationship: the public player is responsible for checking compliance of the codes and standards, applied by the private player. At the same time, the latter in the case of discrepancies between decisions made by the public player and the actual facts, can refer directly to the District and the Building Logbook, resolving the dispute in a simple and effective manner. The flows are not related to the whole data compiled in the Logbooks, it is possible and advisable, both for private and public stakeholders, to verify only certain specific issues.

\section{Discussion and Conclusions}

The tools presented can be considered useful for data collection, update and management with regards to the built environment, at different levels of analysis. In one case considering the building, the control of private properties can be considered the main aim. On the other hand, considering the urban level, the primary objective concerns the management of the public spaces. The Building and the District Logbook can be considered as a "support tool" to prevent disputes among stakeholders, caused by 
a potentially scarce knowledge and/or availability of the district's status and of the building's condition.

Often, when information is requested, the lack of data due to the scarce standardization and attention during storage and management phases, causes the loss of a great amount of time and crucial resources. Moreover, when the competences of private and public actors are not well defined, or there is an overlapping between management of technical, economic and operational issues, the presence of a suitable data collection like the logbook allows users to overcome such conflicts.

The tools, in a wider contest, can be inserted in the data engineering process, this is an approach that should be adopted, when dealing with management of the digital built environment. This could lead to the development of an Asset Information Model (AIM), namely a modular information system able to support informed decision-making and asset management processes. The AIM is featured as a digital model of the asset. It can be composed of a 3D graphical model of the building, information concerning technical characteristics of elements and a collection of documentation relating to safety, permissions, and responsibility with regards to the asset and its components. Thus, concerning the documental part, it can be considered as a translation of the Logbooks into digital terms.

A hypothesis of application of what has been developed concerns the connection between data relating to the energy certifications of buildings and their positioning on the territory. In this context, information was considered to be included in databases for the registration of energy certificates of buildings (CENED), with information that is typical of the Building Logbook, both from the point of view of the description of technological aspects and the condition assessment of the buildings.

The building is located in specific areas/municipalities (whose data can be collected in the District Logbook), which have specific rules of use. Through the proposed tools it is immediately possible to create thematic maps through which to represent the "quality" of the building from the point of view of energy consumption. The use of this procedure could potentially have multiple effects, for example:

- the private investor could verify the presence of low energy consumption areas in the territory as well as individual buildings with the best performance, and direct their investments accordingly;

- linking the thematic map of the energy survey with the real estate values of the different municipal areas, it is possible to verify the influence that energy certification can have on the trend of the real estate values themselves;

- the municipality can verify on the territory which and how many buildings are compliant with current laws in terms of energy consumption, discriminating between new and old buildings, checking, in case of the request for incentives, that the works are carried out properly;

- by locating the presence of non-certified public buildings, their intended use (e.g., schools) and their "influence" on the surrounding area (e.g., distribution of students by age group), a municipality could plan the renovation and/or divestment and request/predispose the necessary budgetary resources appropriately. 
It is clear that the set of necessary information is not only linked to the proposed tools but is part of a broader model for managing a variety of data, to be analyzed and managed according to different levels of detail.

A future challenge to be addressed concerns the precise definition of processes for data collection and management relating to the definition of the operators involved and intended use.

\section{References}

Dejaco MC, Maltese S, Re Cecconi F (2017a) Il fascicolo del fabbricato. Maggioli Editore, Santarcangelo di Romagna, p 204

Dejaco MC, Moretti N, Re Cecconi F (2017b) Streamlined management of the built environment: the district and the building logbook as risk prevention tools. ISTeA 2017-re-shaping. Constr Ind [Internet]. 185-194. https://re.public.polimi.it/handle/11311/1032396\#.WnHPYpM-euU. [cited 2018 Jan 31]

Dejaco MC, Re Cecconi F, Maltese S (2017c) Key performance indicators for building condition assessment. J Build Eng [Internet] 9:17-28. http://linkinghub.elsevier.com/retrieve/pii/ S2352710216302893

Gabellini P (2012) Tecniche urbanistiche. Carocci Editore, Roma, p 516

Lee P-C, Wang Y, Lo T-P, Long D (2018) An integrated system framework of building information modelling and geographical information system for utility tunnel maintenance management. Tunn Undergr Space Technol 79:263-273

Lotfi S, Habibi K, Meshkini A, Koohsari MJ (2008) New multicritera approach for urban facility management by applying GIS. World Appl Sci J [Internet]

Mignard C, Nicolle C (2014) Merging BIM and GIS using ontologies application to urban facility management in ACTIVe3D. Comput Ind [Internet] 65(9):1276-1290. http://dx.doi.org/10.1016/ j.compind.2014.07.008

Moretti N, Maltese S, Dejaco MC, Re Cecconi F (2017) GIS supporting surveys for urban sustainability assessment. In: LC3 2017 volume I-proceedings of the joint conference on computing in construction (JC3), 4-7 July 2017, Heraklion, Greece. Volume I (July), pp 905-912

Moretti N, Dejaco MCC, Maltese S, Re Cecconi F (2018) An information management framework for optimised urban facility management. In: 35th international symposium on automation and robotics in construction (ISARC 2018), pp 381-387

Re Cecconi F, Dejaco MC, Maltese S (2014) Efficiency indexes for building condition assessment. Int J Hous Sci Appl [Internet] 38(4):271-279. http://www.housingscience.org/html/publications/ pdf/38-4-7.pdf. [cited 2019 Jun 24]

Re Cecconi F, Maltese S, Dejaco MC (2017) Leveraging BIM for digital built environment asset management. Innov Infrastruct Solut [Internet] 2(1):14. http://link.springer.com/10.1007/s41062017-0061-z

Sharifi A, Murayama A (2014) Neighborhood sustainability assessment in action: cross-evaluation of three assessment systems and their cases from the US, the UK, and Japan. Build Environ $72: 243-258$

UNI (2012) UNI 11447:2012. Urban facility management services. Guidelines to set and program contracts

Volk R, Stengel J, Schultmann F (2014) Building Information Modeling (BIM) for existing buildings-literature review and future needs. Autom Constr [Internet] 38:109-127. http://dx.doi.org/ 10.1016/j.autcon.2013.10.023 
Open Access This chapter is licensed under the terms of the Creative Commons Attribution 4.0 International License (http://creativecommons.org/licenses/by/4.0/), which permits use, sharing, adaptation, distribution and reproduction in any medium or format, as long as you give appropriate credit to the original author(s) and the source, provide a link to the Creative Commons license and indicate if changes were made.

The images or other third party material in this chapter are included in the chapter's Creative Commons license, unless indicated otherwise in a credit line to the material. If material is not included in the chapter's Creative Commons license and your intended use is not permitted by statutory regulation or exceeds the permitted use, you will need to obtain permission directly from the copyright holder.

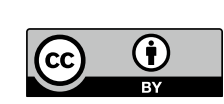

